\title{
Effect of Porcine Collagen Peptides on the Rheological and Sensory Properties of Ice Cream
}

\author{
Liying Li, Jae-Hyeong Kim, Yeon-Ji Jo, Sang-Gi Min*, and Ji-Yeon Chun* \\ Department of Bioindustrial Technologies, Konkuk University, Seoul 143-701, Korea
}

\begin{abstract}
The effects of low molecular-weight collagen peptides derived from porcine skin were investigated on the physicochemical and sensorial properties of chocolate ice cream. Collagen peptides less than $1 \mathrm{kDa}$ in weight were obtained by sub-critical water hydrolysis at a temperature of $300^{\circ} \mathrm{C}$ and a pressure of 80 bar. Ice cream was then prepared with gelatin powder and porcine skin hydrolysate (PSH) stabilizers mixed at seven different ratios (for a total of $0.5 \mathrm{wt} \%$ ). There was no significant difference in color between the resulting ice cream mixtures. The increase in apparent viscosity and shear thinning of the ice cream was more moderate with PSH added than with gelatin. Moreover, the samples containing more than $0.2 \mathrm{wt} \%$ PSH had enhanced melting resistance, while the mixture with $0.2 \mathrm{wt} \% \mathrm{PSH}$ had the lowest storage modulus at $-20^{\circ} \mathrm{C}$ and the second highest loss modulus at $10^{\circ} \mathrm{C}$, indicating that this combination of hydrocolloids leads to relatively softer and creamier chocolate ice cream. Among the seven types of ice creams tested, the mixture with $0.2 \mathrm{wt} \% \mathrm{PSH}$ and $0.3 \mathrm{wt} \%$ gelatin had the best physicochemical properties. However, in sensory evaluations, the samples containing PSH had lower chocolate flavor scores and higher off-flavor scores than the sample prepared with just $0.5 \mathrm{wt} \%$ gelatin due to the strong off-flavor of PSH.
\end{abstract}

Key words: porcine skin, low molecular-weight collagen peptides, sub-critical water hydrolysis, ice cream, stabilizers

Received October 8, 2014 / Revised December 2, 2014 / Accepted December 4, 2014

\section{Introduction}

Ice cream is a frozen product consisting of air cells, ice crystals, and fat droplets dispersed in a serum phase. During processing, ice cream is frozen rapidly by removing heat from the mix while stirring to incorporate air (Marshall et al., 2003). Stabilizers, predominantly hydrocolloids, are used during preparation to provide a smooth texture, for shape retention during melting, and to increase the viscosity of the mix (Goff and Hartel, 2004; Marshall et al., 2003). Most importantly, these cryoprotective hydrocolloids retard the growth of ice crystals during storage, especially during temperature fluctuations, but they neither change the thermodynamics of the ice cream mix nor alter ice nucleation kinetics (Marshall et al., 2003; Muhr et al., 1986).

Gelatin, derived from collagen obtained from various

*Corresponding author: Ji-Yeon Chun, Department of Bioindustrial Technologies, Konkuk University, Seoul 143-701, Korea. Tel.: +82-2-450-3672, 3680, Fax: +82-2-455-1044, E-mail: chunjiyeon@konkuk.ac.kr; Sang-Gi Min, Department of Bioindustrial Technologies, Konkuk University, Seoul 143-701, Korea. Tel.: +82-2-450-3672, 3680, Fax: +82-2-455-1044, Email: minsg@konkuk.ac.kr animal by-products, is one of the principal materials used as an ice cream stabilizer. It disperses easily and does not cause wheying-off or foaming. However, gelatin is a relatively expensive stabilizer only effective at high concentrations and tends to offer poor protection against the effects of heat shock. It also requires prolonged aging (Wang and Damodaran, 2009). With these drawbacks in mind, low molecular-weight (600-2,700 Da) collagen peptides derived from Alcalase hydrolysis of bovine gelatin have been found to inhibit ice recrystallization in a supercooled ice cream mix (Wang and Damodaran, 2009). These can therefore be considered as new stabilizers for ice cream production.

Other than their use as stabilizers, collagen peptides have also attracted attention for their bioactive properties. An antihypertensive peptide has been obtained from porcine skin collagen (Ichimura et al., 2009). Numerous studies have investigated the antioxidant properties of peptides obtained from collagenous sources; these may protect living cells against free radical mediated oxidative damage (Kim et al., 2001).

Subcritical water, viz. pressurized water heated above its boiling point but below the critical point of $374^{\circ} \mathrm{C}$ and $221 \mathrm{MPa}$, has unique properties (Lee et al., 2013). Com- 
pared with other hydrolysis methods, the "green" approach of using water as a solvent in place of hazardous substances also expedites processing (Alargov et al., 2002; Lee et al., 2013). Sub-critical water hydrolysis has been employed to efficiently extract amino acids from collagen (Zhu et al., 2011). Furthermore, the effects of high pressure/high temperature (sub-critical water) treatment on porcine placenta have also been reported (Lee et al., 2013).

In this study therefore, low molecular-weight collagen derived from porcine skin $(<1 \mathrm{kDa}$, porcine skin hydrolysate, PSH) was extracted using sub-critical water $\left(300^{\circ} \mathrm{C}\right.$ and 80 bar). Chocolate ice cream was then prepared using PSH which contained $5 \mathrm{wt} \%$ collagen peptides as a stabilizer and cocoa powder because of its strong off-flavor. The effects of different PSH contents on the physicochemical and sensorial properties of chocolate ice cream were analyzed.

\section{Materials and Methods}

\section{Preparation of porcine skin hydrolysates}

Porcine skin hydrolysates (PSH) were produced by subcritical water hydrolysis. The treatment conditions were optimized in a previous study (Kim et al., 2014). Porcine skin was bought from a local butcher's shop (Daeho Chooksan, Korea). The skin was immersed in $70^{\circ} \mathrm{C}$ water for $2 \mathrm{~h}$ to remove fat and other residues and then sliced into $0.5 \mathrm{~cm} \times 0.5 \mathrm{~cm}$ pieces. These were homogenized first for $3 \mathrm{~min}$ using a four-wing blade blender (CNHR26, Bosch, China) and then at 25,000 rpm for $5 \mathrm{~min}$ using an Ultra-Turrax ${ }^{\circledR}$ blender (T25, IKA Labotechnik, Germany). The sub-critical water system $\left(300^{\circ} \mathrm{C}\right.$ and 80 bar) was composed of a control box, vessel (reactor), water bath, heater, temperature controller, and pressure controller (SFE SYSTEM, CS-1000, REXO, Korea). Porcine skin mixed with distilled water $(1: 2$, w/w) was then hydrolyzed and cooled directly in this system whose temperature and pressure were reduced down to $40-45^{\circ} \mathrm{C}$ and 0.1 bar, respectively in a $4^{\circ} \mathrm{C}$ water bath with coolant circulation. All processing steps were completed within $1 \mathrm{~h}$.

\section{Characterization of the porcine skin hydrolysates}

All characterizations were performed as described by $\mathrm{Kim}$ et al. (2014). The samples were centrifuged at 10,000 $\mathrm{g}$ for $5 \mathrm{~min}$ and the molecular weights of the peptides in the supernatant were determined by gel permeation chromatography (GPC, YL 9100, Younglin Instrument Co. Ltd., Korea). The amino acid profile was determined at the Ani- mal Resources Research Center in Konkuk University (S4300 Amino Acid Reaction Module, Systeme \& Komponenten analytischer Meßtechnik, Germany). The free amino group content was determined using the method of Benjakul and Morrissey (1997), and expressed in terms of L-leucine (Nagarajan et al., 2012). The pH and color of the filtered $\mathrm{PSH}$ solution were respectively determined using a pH meter (Model S220, Mettler Toledo GmbH, Switzerland) and a colorimeter (CR-210 Chroma-meter, Minolta, Japan) calibrated using a white standard (CIE $L^{*}$ $=+97.83$, CIE $a^{*}=-0.43$, CIE $\left.b^{*}=+1.96\right)$.

\section{Ice cream preparation}

Different ice cream samples were prepared with the stabilizer type and content varied as follows: $0.5 \mathrm{wt} \%$ gelatin (Hayashi Pure Chemical Industries Ltd., Japan), 0.5 wt $\%$ PSH, PSH 0.1 (0.1 wt $\%$ PSH +0.4 wt $\%$ gelatin $)$, PSH 0.2 (0.2 wt $\%$ PSH+0.3 wt $\%$ gelatin), $\mathrm{PSH} 0.25(0.25$ $\mathrm{wt} \% \mathrm{PSH}+0.25 \mathrm{wt} \%$ gelatin), $\mathrm{PSH} 0.3(0.3 \mathrm{wt} \% \mathrm{PSH}+$ $0.2 \mathrm{wt} \%$ gelatin), and $\mathrm{PSH} 0.4(0.4 \mathrm{wt} \% \mathrm{PSH}+0.1 \mathrm{wt} \%$ gelatin). The ice cream used in this study consisted of 11 wt $\%$ milk fat and 59.3 wt $\%$ water (provided as milk and whipped cream, Maeil Dairies Industry Co., Ltd., Korea), $10 \mathrm{wt} \%$ non-fat milk solids (skimmed milk powder, Maeil Dairies Industry Co., Ltd., Korea), 12 wt\% sucrose (CJ CheilJedang Corp., Korea), 4 wt $\%$ corn syrup solids (Dextrose Equivalent 42, Grain Processing Corp., USA), 0.2 wt \% glyceryl monosearate (Daejung Chemicals \& Metals Co., Ltd., Korea), and 3 wt \% cocoa powder (ADM Cocoa Pte. Ltd., Singapore) (Table 1).

All ingredients were mixed, pasteurized at $70^{\circ} \mathrm{C}$ for 30 min, and then homogenized using a high-speed homogenizer (Ingenieurbüro CAT M. Zipperer GmbH, Germany) for $30 \mathrm{~min}$ at $11,000 \mathrm{rpm}$. The ice cream mix was then cooled down to $4^{\circ} \mathrm{C}$ and aged overnight. The aged ice cream mix was frozen in a freezer (Sani-serv $4071 \mathrm{E}$, USA) at a drawer temperature of $-5^{\circ} \mathrm{C}$, and packed into 30 $\mathrm{mm} \times 5 \mathrm{~mm}$ containers and $120 \mathrm{~mL}$ specimen cups (SPL Lifesciences Co., Ltd., Korea). The ice creams were hardened and stored at $-20^{\circ} \mathrm{C}$ for $24 \mathrm{~h}$ in a freezer (CRFD0621, Samsung Electronics Co., Ltd., Korea). The overall experimental procedure was repeated three times giving a total of 21 formulations.

\section{Rheological properties}

\section{Ice cream viscosity}

A rheometer (Anton Paar, MCR 302, Austria) with a concentric cylinder (CC27) was used to determine the 
Table 1. Composition of the chocolate ice cream samples used in the present study

\begin{tabular}{|c|c|c|c|c|c|c|c|c|c|}
\hline Sample & $\begin{array}{l}\text { Gelatin } \\
\text { (wt\%) }\end{array}$ & $\begin{array}{l}\text { PSH } \\
(w t \%)\end{array}$ & $\begin{array}{c}\text { Milk fat } \\
(\mathrm{wt} \%)\end{array}$ & $\begin{array}{l}\text { MSNF } \\
(w t \%)\end{array}$ & $\begin{array}{l}\text { Sucrose } \\
(w t \%)\end{array}$ & $\begin{array}{l}\text { Corn syrup } \\
\text { solids (wt } \% \text { ) }\end{array}$ & $\begin{array}{c}\text { Glyceryl } \\
\text { monosearate (wt\%) }\end{array}$ & $\begin{array}{c}\text { Cocoa powder } \\
(\text { wt } \%)\end{array}$ & $\begin{array}{l}\text { Water } \\
(w t \%)\end{array}$ \\
\hline Control & 0.5 & 0 & & & & & & & \\
\hline PSH 0.1 & 0.4 & 0.1 & & & & & & & \\
\hline PSH 0.2 & 0.3 & 0.2 & & & & & & & \\
\hline PSH 0.25 & 0.25 & 0.25 & 11 & 10 & 12 & 4 & 0.2 & 3 & 59.3 \\
\hline PSH 0.3 & 0.2 & 0.3 & & & & & & & \\
\hline PSH 0.4 & 0.1 & 0.4 & & & & & & & \\
\hline PSH 0.5 & 0 & 0.5 & & & & & & & \\
\hline
\end{tabular}

viscosity of the ice cream mixes after aging. The measurements were carried out for shear rates ranging from $1 \mathrm{~s}^{-1}$ to $100 \mathrm{~s}^{-1}$ at $4^{\circ} \mathrm{C}$. The apparent viscosity (Kokini viscosity) of the ice cream mixes, representing the feeling of low-viscosity foods in the mouth, was calculated at a shear rate of $50 \mathrm{~s}^{-1}$ (Akhtar et al., 2006; Kokini 1987; Stanley and Taylor, 1993). The Ostwald-de Waele model was used to relate the shear rate and the shear stress, through which the consistency coefficient $(\mathrm{K})$ and flow behavior index (n) can be calculated as follows:

$$
\sigma=\mathrm{K} \gamma^{\mathrm{n}}
$$

where $\sigma$ is the shear stress $(\mathrm{Pa}), \mathrm{K}$ is the consistency coefficient $\left(\mathrm{Pa} \cdot \mathrm{s}^{\mathrm{n}}\right), \gamma$ is the shear rate $\left(\mathrm{s}^{-1}\right)$, and $\mathrm{n}$ is the flow behavior index (dimensionless).

\section{Oscillatory rheometry}

Oscillatory thermo-rheometry measurements were carried out (Wildmoser et al., 2004) using a rheometer (Anton Paar, MCR 302, Austria) with a plate-plate geometry (PP25-S, plate diameter: $25 \mathrm{~mm}$ ) to determine the dynamic rheological properties of the ice cream mixtures. A movable hood covering the plate-plate setup reduced temperature fluctuations with the environment. The test was performed at a constant strain $\gamma=0.2 \%$ and angular frequency $\omega=10 \mathrm{~s}^{-1}$. A $2 \mathrm{~mm}$ gap was maintained between the plates. The temperature was gradually increased from $20^{\circ} \mathrm{C}$ to $10^{\circ} \mathrm{C}$ at a constant heating rate of $2^{\circ} \mathrm{C} / \mathrm{min}$. The storage modulus $\mathrm{G}^{\prime}$ and the loss modulus $\mathrm{G}^{\prime \prime}$ were obtained from measurements, which respectively characterize the elastic and viscous behaviors of the ice cream.

\section{Melting test}

Each time one sample was placed on a stainless mesh on top of a plastic funnel attached to a stand, and a plastic sample dish was placed on an electronic balance (BL$220 \mathrm{H}$, Shimadzu Corp., Japan). This ice-cream melting system was placed in an incubator (SW-90F, Sangwoo,
Korea) maintained at $25^{\circ} \mathrm{C}$. The balance was connected to a computer and the weight of the ice cream melt was automatically calculated every minute (Fig. 1).

\section{Color differences}

The difference in color of the ice cream after hardening was measured using a Chroma-meter (CR-400, Konica Minolta Optics, Inc., Japan). Results were expressed using the $L^{*} a^{*} b^{*}$ scale, for lightness, redness, and yellowness, respectively. The measurements were calibrated to a

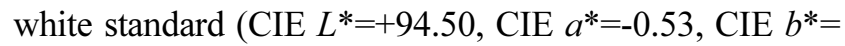
$+3.14)$ and the total color difference $\left(\Delta E^{*}\right)$ was calculated using the following equation:

$$
\Delta E^{*}=\sqrt{\left(L_{2}^{*}-L_{1}^{*}\right)^{2}+\left(a_{2}^{*}-a_{1}^{*}\right)^{2}+\left(b_{2}^{*}-b_{1}^{*}\right)^{2}}
$$

where $\left(L_{1}^{*}, a_{1}^{*}, b_{1}^{*}\right)$ is the reference color and $\left(L_{2}^{*}, a_{2}^{*}\right.$, $\left.b_{2}^{*}\right)$ is the target color.

\section{Sensory properties}

Sensory characteristics including the appearance, chocolate flavor, off-flavor, bitterness, creaminess, iciness, hardness, sweetness, smoothness, and coarseness of the ice

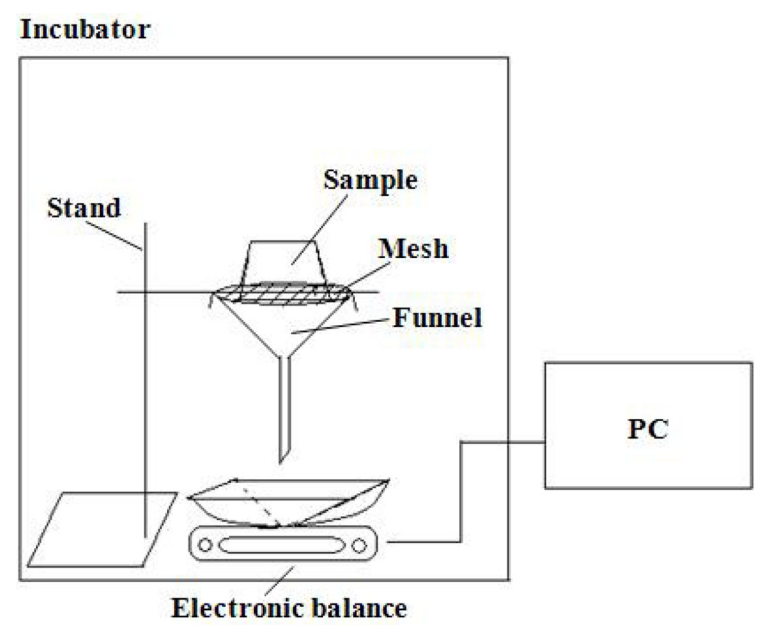

Fig. 1. Schematic diagram of the ice cream melting system. 
cream were evaluated by trained panelists. In these sessions, the attributes and assessment techniques were defined and a practical sample evaluation was performed. Sensory evaluations were carried out using a 5-point scale, with 1 representing "non-existent or imperceptible" and 5 representing "very intense" properties.

\section{Statistical analysis}

All assays were carried out in triplicate. The data were expressed as means with standard deviations and statistical analysis was performed using the Origin Pro 8 (OriginLab, USA) and SPSS 20.0 (SPSS Institute, USA) software. Means were subjected to analysis of variance by Duncan's multiple range test and Least-significant difference at $p<0.05$.

\section{Results and Discussion}

\section{Physical properties of porcine skin hydrolysates}

In this study, PSH was produced through an optimized sub-critical water treatment $\left(300^{\circ} \mathrm{C}\right.$ and 80 bar) and the physical properties of the resulting PSH were similar to those described in our previous report (Kim et al., 2014). Representative characteristics of the PSH used here to prepare ice cream are shown in Table 2 and Fig. 2. The relatively high $\mathrm{pH}, 9.22$, is due to the increased self-ionization of water during sub-critical water treatments (Brunner, 2009, 2014; Penninger et al., 2000; Ravber et al., 2015; Watchararuji et al., 2008). The molecular weight peaks obtained following the sub-critical water treatment of PSH are distributed between $434 \mathrm{Da}$ and $626 \mathrm{Da}$. The free amino group content was $57.18 \mathrm{mM}$, with the concentrations of Gly (28\%) and Ala (13.1\%) being the highest. In terms of color, the lightness, redness and yellow-

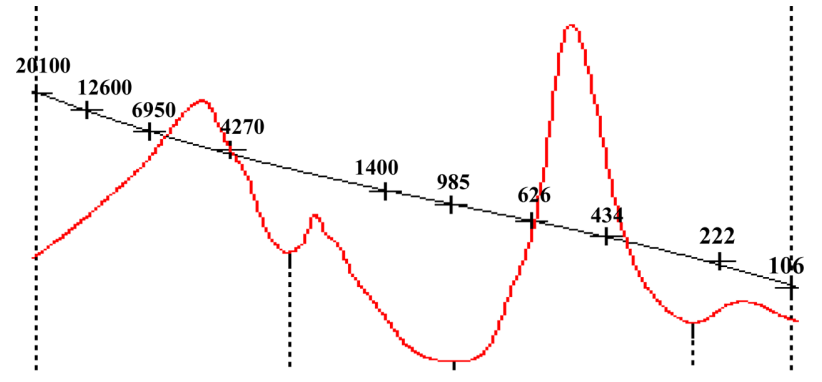

Molecular weight (Da)

Fig. 2. Gel permeation chromatography graph obtained for PSH with crosses indicating the molecular weights of constituents.

ness of the PSH were 33.6, 0.59, and 11.4, respectively.

\section{Viscosity of the ice cream mixes}

Viscosity, one of the most important rheological properties of ice cream mix, is influenced by many factors notably its composition and the stabilizer type and content. By forming a three-dimensional network of hydrated molecules, hydrocolloids enhance the water-binding capacity of the ice cream mix (Kus et al., 2005). Table 3 shows the values measured for the Kokini viscosity, consistency coefficient, and flow behavior index of the ice cream mixes prepared with different PSH-to-gelatin ratios. The flow behavior indexes are all less than one, characteristic of the shear thinning behavior reported previously (Kaya and Tekin, 2001). Ice cream mixes with higher consistency coefficients are considered more viscous. Soukoulis et al. (2009) related enhanced apparent viscosity by increased Kokini viscosities and consistency coefficients, and increased shear thinning by lower flow behavior indexes. Here, the Kokini viscosity and consistency coefficient

Table 2. Physical properties of porcine skin collagen extract

\begin{tabular}{ccccccc}
\hline \hline & $\mathrm{pH}$ & Average molecular weight $(\mathrm{Da})$ & Free amino acid $(\mathrm{mM})$ & $L^{*}$-value & $a^{*}$-value & $b^{*}$-value \\
\hline $\mathrm{PSH}$ & $9.22 \pm 0.01$ & 500 & $57.18 \pm 0.69$ & $33.6 \pm 0.05$ & $0.59 \pm 0.06$ & $11.4 \pm 0.06$ \\
\hline
\end{tabular}

Table 3. Effect of hydrocolloids on the Kokini viscosity, consistency coefficient, and flow behavior index of different chocolate ice cream mixes

\begin{tabular}{cccc}
\hline \hline Treatments & Kokini viscosity $\eta_{50}($ Pa·s $)$ & Consistency coefficient K $\left(\right.$ Pa·s $\left.^{\mathrm{n}}\right)$ & Flow behavior index n $^{\mathrm{a}}$ \\
\hline Control & $0.43 \pm 0.06^{\mathrm{a}}$ & $2.65 \pm 0.31^{\mathrm{a}}$ & $0.54 \pm 0.04^{\mathrm{d}}$ \\
PSH 0.1 & $0.28 \pm 0.07^{\mathrm{b}}$ & $0.58 \pm 0.23^{\mathrm{b}}$ & $0.83 \pm 0.04^{\mathrm{c}}$ \\
PSH 0.2 & $0.19 \pm 0.03^{\mathrm{c}}$ & $0.32 \pm 0.09^{\mathrm{bc}}$ & $0.87 \pm 0.03^{\mathrm{b}}$ \\
PSH 0.25 & $0.15 \pm 0.02^{\mathrm{cd}}$ & $0.24 \pm 0.03^{\mathrm{c}}$ & $0.88 \pm 0.01^{\mathrm{ab}}$ \\
PSH 0.3 & $0.15 \pm 0.04^{\mathrm{cd}}$ & $0.24 \pm 0.08^{\mathrm{c}}$ & $0.89 \pm 0.02^{\mathrm{ab}}$ \\
PSH 0.4 & $0.11 \pm 0.01^{\mathrm{d}}$ & $0.14 \pm 0.01^{\mathrm{c}}$ & $0.93 \pm 0.01^{\mathrm{a}}$ \\
PSH 0.5 & $0.10 \pm 0.00^{\mathrm{d}}$ & $0.13 \pm 0.00^{\mathrm{c}}$ & $0.92 \pm 0.01^{\mathrm{ab}}$ \\
\hline
\end{tabular}

Mean \pm SD values were calculated based on at least 3 repeat measurements.

${ }^{\mathrm{a}-\mathrm{d}}$ Different letters in the same column indicate significantly different values $(p<0.05)$. 
increases and the flow behavior index decreases for lower PSH (higher gelatin) concentrations, indicating that PSH leads to a more moderate increase in ice cream viscosity than gelatin. This may be due to the low peptide content of collagen, only $5 \mathrm{wt} \%$ in PSH. There is a significant $(p<0.05)$ difference between the Kokini viscosities of the control, PSH 0.1, and PSH 0.2 ice cream mixes. The control sample has the highest Kokini viscosity $(0.43 \pm 0.06$ $\mathrm{Pa} \cdot \mathrm{s})$, followed by PSH $0.1(0.28 \pm 0.07 \mathrm{~Pa} \cdot \mathrm{s})$ and PSH 0.2 $(0.19 \pm 0.03 \mathrm{~Pa} \cdot \mathrm{s})$. However, although the other mixes had lower Kokini viscosities, these differences were not significant $(p>0.05)$.

\section{Oscillatory rheometry}

Oscillatory tests are used to determine the viscoelastic properties of complex food systems (Dolz et al., 2006). Temperature has an important impact on the structure of ice cream, with ice crystal microstructures dominating the rheological behavior of frozen ice cream in the low temperature range, from $-20^{\circ} \mathrm{C}$ to $-10^{\circ} \mathrm{C}$. Thus, the storage modulus $\mathrm{G}^{\prime}$ and loss modulus $\mathrm{G}^{\prime \prime}$ below $-10^{\circ} \mathrm{C}$ report on the ice crystal size and rigidity of the ice cream. As ice is melted away under constant heating from $0^{\circ} \mathrm{C}$ to $10^{\circ} \mathrm{C}$, the loss modulus G", which characterizes the viscosity of the ice cream, can be correlated with creaminess (Wildmoser et al., 2004).

The influence of hydrocolloids on the ice cream storage modulus at $-20^{\circ} \mathrm{C}$ and its loss modulus at $10^{\circ} \mathrm{C}$ are presented in Figs. 3 and 4, respectively. The PSH 0.2 and PSH 0.4 samples have the lowest storage modulus at $-20^{\circ} \mathrm{C}$ $(0.45 \pm 0.03 \mathrm{MPa}$ and $0.48 \pm 0.03 \mathrm{MPa}$, respectively). These two combinations of stabilizers are therefore the most effective at inhibiting ice crystal growth during ice cream preparation. The control ice cream mix with the highest Kokini viscosity is also the creamiest, with the highest loss modulus at $10^{\circ} \mathrm{C}(34.01 \pm 2.14 \mathrm{~Pa}, p<0.05)$ among the different samples, but also with the largest ice crystals as revealed by the highest storage modulus at $-20^{\circ} \mathrm{C}(1.11 \pm$ $0.03 \mathrm{MPa}, p<0.05)$. The second and third most viscous mixes (PSH 0.1 and PSH 0.2) are also creamy with no significant difference $(p>0.05)$ between their loss modulus at $10^{\circ} \mathrm{C}(21.27 \pm 1.25 \mathrm{~Pa}$ and $20.63 \pm 3.11 \mathrm{~Pa}$, respectively).

\section{Melting resistance of the ice cream}

Melting resistance is an important parameter used to evaluate the physical stability of frozen ice cream. According to Marshall et al. (2003), hydrocolloids improve the resistance to melting due to the enhancement of water-

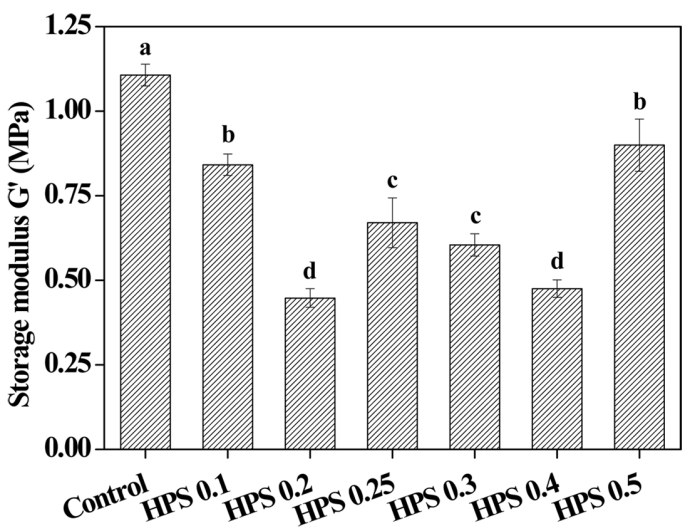

Fig. 3. The influence of hydrocolloids on the ice cream storage modulus at $-\mathbf{2 0}^{\circ} \mathbf{C}$. Control, $0.5 \mathrm{wt} \%$ gelatin; PSH 0.1 , $0.1 \mathrm{wt} \% \mathrm{PSH}+0.4 \mathrm{wt} \%$ gelatin; PSH 0.2, $0.2 \mathrm{wt} \% \mathrm{PSH}+$ $0.3 \mathrm{wt} \%$ gelatin; PSH $0.25,0.25 \mathrm{wt} \% \mathrm{PSH}+0.25 \mathrm{wt} \%$ gelatin; PSH 0.3, $0.3 \mathrm{wt} \%$ PSH $+0.2 \mathrm{wt} \%$ gelatin; PSH 0.4 , $0.4 \mathrm{wt} \% \mathrm{PSH}+0.1 \mathrm{wt} \%$ gelatin; PSH $0.5,0.5 \mathrm{wt} \% \mathrm{PSH}$. Mean \pm SD values were calculated based on at least 3 repeat measurements. ${ }^{\mathrm{a}-\mathrm{d}}$ Different letters indicate significantly different $(p<0.05)$ values.

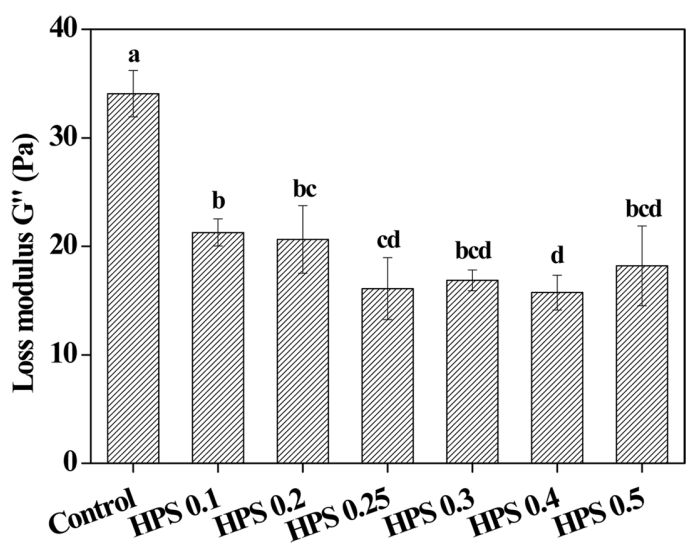

Fig. 4. The influence of hydrocolloids on the ice cream loss modulus at $10^{\circ} \mathbf{C}$. Control, $0.5 \mathrm{wt} \%$ gelatin; PSH $0.1,0.1$ $\mathrm{wt} \% \mathrm{PSH}+0.4 \mathrm{wt} \%$ gelatin; $\mathrm{PSH} 0.2,0.2 \mathrm{wt} \% \mathrm{PSH}+0.3$ wt $\%$ gelatin; PSH $0.25,0.25 \mathrm{wt} \% \mathrm{PSH}+0.25 \mathrm{wt} \%$ gelatin; PSH 0.3, 0.3 wt $\%$ PSH $+0.2 \mathrm{wt} \%$ gelatin; PSH 0.4, $0.4 \mathrm{wt} \%$ $\mathrm{PSH}+0.1 \mathrm{wt} \%$ gelatin; PSH 0.5: $0.5 \mathrm{wt} \% \mathrm{PSH}$. Mean $\pm \mathrm{SD}$ values were calculated based on at least 3 repeat measurements. ${ }^{\mathrm{a}-\mathrm{d}}$ Different letters indicate significantly different $(p<0.05)$ values.

holding and microviscosity they provide. However, as shown in Table 4, although the ice creams with higher viscosities (control and PSH 0.1) have longer first-dropping times $(35.67 \pm 2.08 \mathrm{~min}$ and $23.33 \pm 2.52 \mathrm{~min}$, respectively), their melting rates $(6.35 \pm 0.78 \mathrm{~g} / \mathrm{min}$ and $4.43 \pm$ $0.16 \mathrm{~g} / \mathrm{min}$, respectively) are significantly higher than those of the other five types of ice cream $(p<0.05)$. This 
Table 4. Effect of hydrocolloids on the melting quality of different chocolate ice cream mixes

\begin{tabular}{ccc}
\hline \hline Treatments & $\begin{array}{c}\text { First dropping time } \\
(\mathrm{min})\end{array}$ & $\begin{array}{c}\text { Melting rate } \\
(\mathrm{g} / \mathrm{min})\end{array}$ \\
\hline Control & $35.67 \pm 2.08^{\mathrm{a}}$ & $6.35 \pm 0.78^{\mathrm{a}}$ \\
PSH 0.1 & $23.33 \pm 2.52^{\mathrm{b}}$ & $4.43 \pm 0.16^{\mathrm{b}}$ \\
PSH 0.2 & $17.00 \pm 3.61^{\mathrm{c}}$ & $4.02 \pm 0.19^{\mathrm{bc}}$ \\
PSH 0.25 & $15.33 \pm 0.58^{\mathrm{c}}$ & $3.66 \pm 0.09^{\mathrm{c}}$ \\
PSH 0.3 & $17.67 \pm 1.53^{\mathrm{c}}$ & $3.55 \pm 0.19^{\mathrm{c}}$ \\
PSH 0.4 & $16.33 \pm 1.15^{\mathrm{c}}$ & $3.71 \pm 0.16^{\mathrm{c}}$ \\
PSH 0.5 & $15.33 \pm 1.15^{\mathrm{c}}$ & $3.69 \pm 0.11^{\mathrm{c}}$ \\
\hline
\end{tabular}

Mean \pm SD values were calculated based on at least 3 repeat measurements.

${ }^{a-c}$ Different letters in the same column indicate significantly different $(p<0.05)$ values.

result is in agreement with Kilara and Chandan (2008), and proves that gelatin is not effective in preventing the effects of heat shock. The ice cream with the third-highest viscosity (PSH 0.2) has a first dropping time and melting rate that are not significantly different $(p>0.05)$ from the values measured for the four remaining samples, indicating that melting resistance is similarly enhanced for PSH concentrations above $0.2 \mathrm{wt} \%$ and gelatin concentrations below $0.3 \mathrm{wt} \%$.

\section{Color differences}

In this study, since the PSH are dark brown, the lightness, redness, and yellowness of the ice cream mixtures were measured to evaluate the effects of hydrocolloids on the color of hardened chocolate ice cream. Note that color differences in fresh ice cream have seldom been investigated. As Table 5 shows, there is no significant difference in color $(p>0.05)$ between the ice creams prepared with different PSH to gelatin ratios, with an average lightness, redness, and yellowness of 42.3, 10.5, and 17.1, respectively. Cocoa powder is similar in color to PSH but darker, therefore varying the PSH concentration does not affect the color of the ice cream. In previous tests of the effect of PSH on vanilla ice cream, its color quality was deemed not acceptable because of stains and darkening.

\section{Sensory evaluation}

The perceived texture and flavor of ice cream are considered to be the most important factors influencing ice cream consumption. In addition to their other effects, hydrocolloids influence the sensory properties of ice cream (Donhowe et al., 1991; Rincon et al., 2006; Soukoulis et al., 2008). Comparing the physicochemical properties of the different fresh samples, the PSH 0.2 composition has

Table 5. Effect of hydrocolloids on lightness, redness, yellowness and total color difference of chocolate ice cream

\begin{tabular}{ccccc}
\hline \hline Treatment & $L^{*}$-value & $a^{*}$-value & $b^{*}$-value & $\Delta E$ \\
\hline Control & $42.53 \pm 0.41$ & $10.71 \pm 0.23$ & $16.84 \pm 0.23$ & $54.91 \pm 0.40$ \\
PSH 0.1 & $43.03 \pm 0.17$ & $10.74 \pm 0.18$ & $16.94 \pm 0.22$ & $54.46 \pm 0.13$ \\
PSH 0.2 & $41.64 \pm 0.85$ & $10.32 \pm 0.11$ & $16.93 \pm 0.44$ & $55.69 \pm 0.93$ \\
PSH 0.25 & $42.39 \pm 0.32$ & $10.37 \pm 0.30$ & $17.25 \pm 0.27$ & $55.07 \pm 0.32$ \\
PSH 0.3 & $41.67 \pm 1.68$ & $10.31 \pm 0.32$ & $17.38 \pm 0.30$ & $55.78 \pm 1.62$ \\
PSH 0.4 & $42.34 \pm 0.25$ & $10.65 \pm 0.19$ & $17.31 \pm 0.19$ & $55.19 \pm 0.27$ \\
PSH 0.5 & $42.32 \pm 0.26$ & $10.32 \pm 0.13$ & $17.12 \pm 0.26$ & $55.10 \pm 0.33$ \\
\hline
\end{tabular}

Mean \pm SD values were obtained from at least 3 repeat measurements.

None of the values are significantly different $(p>0.05)$.

Table 6. Effect of hydrocolloids on the sensory attributes of different chocolate ice cream mixtures

\begin{tabular}{cccc}
\hline \hline Sensory parameters & \multicolumn{3}{c}{ Treatments } \\
\cline { 2 - 4 } & Control & PSH 0.5 & $3.40 \pm 0.89^{\mathrm{a}}$ \\
\hline Appearance & $3.60 \pm 1.34^{\mathrm{a}}$ & $4.20 \pm 0.84^{\mathrm{a}}$ & $2.60 \pm 0.55^{\mathrm{b}}$ \\
Chocolate flavor & $4.20 \pm 1.30^{\mathrm{a}}$ & $2.60 \pm 0.89^{\mathrm{b}}$ & $3.60 \pm 1.52^{\mathrm{a}}$ \\
Off-flavor & $1.40 \pm 0.55^{\mathrm{b}}$ & $3.40 \pm 1.34^{\mathrm{a}}$ & $3.00 \pm 0.71^{\mathrm{a}}$ \\
Bitterness & $3.60 \pm 0.55^{\mathrm{a}}$ & $3.80 \pm 1.30^{\mathrm{a}}$ & $3.80 \pm 1.30^{\mathrm{a}}$ \\
Creaminess & $2.80 \pm 1.10^{\mathrm{a}}$ & $3.00 \pm 1.00^{\mathrm{a}}$ & $1.80 \pm 0.84^{\mathrm{a}}$ \\
Iciness & $2.00 \pm 1.00^{\mathrm{a}}$ & $2.00 \pm 0.71^{\mathrm{a}}$ & $2.20 \pm 0.84^{\mathrm{b}}$ \\
Hardness & $3.60 \pm 0.55^{\mathrm{a}}$ & $2.20 \pm 0.84^{\mathrm{b}}$ & $3.60 \pm 1.14^{\mathrm{a}}$ \\
Sweetness & $3.20 \pm 1.10^{\mathrm{a}}$ & $2.60 \pm 0.89^{\mathrm{a}}$ & $3.20 \pm 1.48^{\mathrm{a}}$ \\
Smoothness & $3.00 \pm 1.00^{\mathrm{a}}$ & $3.40 \pm 0.89^{\mathrm{a}}$ & $2.60 \pm 0.89^{\mathrm{a}}$ \\
Coarseness & $3.80 \pm 0.84^{\mathrm{a}}$ & $2.60 \pm 1.14^{\mathrm{a}}$ & \\
\hline
\end{tabular}

Mean \pm SD values were calculated based on at least 5 repeat measurements.

${ }^{\mathrm{a}, \mathrm{b}}$ Different letters in the same row indicate significantly different values $(p<0.05)$. 
a relatively high Kokini viscosity, enhanced resistance to melting, the lowest storage modulus at $-20^{\circ} \mathrm{C}$, and the second highest loss modulus at $10^{\circ} \mathrm{C}$. This mixture was therefore chosen for sensory evaluations along with the control and PSH 0.5 samples.

As shown in Table 6, there was no significant difference $(p>0.05)$ between the three samples in terms of appearance, bitterness, creaminess, iciness, sweetness, smoothness, or coarseness. Morris (1995) reported that increased shear thinning of hydrocolloids may be associated with better flavor perception. Indeed, in the present study, the sample with $0.5 \mathrm{wt} \%$ gelatin, which exhibited the most shear thinning, gained a significantly higher chocolate flavor score $(p<0.05)$. As expected since PSH is known to cause strong off-flavors, the PSH 0.2 and PSH 0.5 mixtures have significantly higher off-flavor scores $(p<0.05)$ compared with the control ice cream. The ice cream produced with $0.5 \mathrm{wt} \%$ gelatin has a significantly higher hardness score $(p<0.05)$ than the other two, which is in agreement with the oscillatory rheometry tests that ice crystal growth is not inhibited effectively in the $0.5 \mathrm{wt} \%$ gelatin sample.

\section{Conclusion}

This study analysed the impact of different PSH-to-gelatin ratios on the physicochemical and sensorial properties of chocolate ice cream. In terms of the physicochemical properties, the ice cream prepared with $0.2 \mathrm{wt} \% \mathrm{PSH}$ and $0.3 \mathrm{wt} \%$ gelatin was optimal among the seven compositions tested, with a relatively high Kokini viscosity, enhanced melting resistance, the lowest storage modulus at $-20^{\circ} \mathrm{C}$, and the second highest loss modulus at $10^{\circ} \mathrm{C}$. However, in the sensory evaluations, the control ice cream ( $0.5 \mathrm{wt} \%$ gelatin) was perceived to have the highest chocolate flavor and the lowest off-flavor, possibly due to the strong off-flavor of PSH. The addition of low molecularweight collagen peptides derived from porcine skin was therefore effective in improving the physical and rheological properties of the ice cream, but its sensory properties were degraded by the off-flavor of PSH. Masking the offflavor of PSH is therefore an important goal for further studies in order to manufacture ideal ice cream products.

\section{Acknowledgements}

Financial support for this study was obtained from the Korean Institute of Planning and Evaluation for Technology in Food, Agriculture, Forest, and Fisheries, Korea
(iPET Project No. 311029-3) and this paper was supported by the KU Research Professor Program of Konkuk University.

\section{References}

1. Akhtar, M., Murray, B. S., and Dickinson, E. (2006) Perception of creaminess of model oil-in-water dairy emulsions: Influence of the shear-thinning nature of a viscosity-controlling hydrocolloid. Food Hydrocolloid. 20, 839-847.

2. Alargov, D., Deguchi, S., Tsujii, K., and Horikoshi, K. (2002) Reaction behaviors of glycine under super- and subcritical water conditions. Orig. Life Evol. Biosph. 32, 1-12.

3. Benjakul, S. and Morrissey, M. T. (1997) Protein hydrolysates from pacific whiting solid wastes. J. Agric. Food Chem. 45, 3423-3430.

4. Brunner, G. (2009) Near critical and supercritical water. Part I. Hydrolytic and hydrothermal processes. J. Supercritical Fluid. 47, 373-381.

5. Brunner, G. (2014) Supercritical fluid science and technology. In: Properties of pure water. Brunner, G. (ed) Elsevier, 5, pp. 9-93.

6. Dolz, M., Hernández, M., and Delegido, J. (2006) Oscillatory measurements for salad dressings stabilized with modified starch, xanthan gum, and locust bean gum. J. Appl. Polym. Sci. 102, 897-903.

7. Donhowe, D. P., Hartel, R. W., and Bradley, R. L. (1991) Determination of ice crystal size distributions in frozen desserts. J. Dairy Sci. 74, 3334-3344.

8. Goff, H. D. and Hartel, R. W. (2004) Ice cream and frozen desserts. In: Handbook of Frozen Foods. Hui, Y. H. (ed) Marcel Dekker Inc, NY, pp. 499-570.

9. Ichimura, T., Yamanaka, A., Otsuka, T., Yamashita, E., and Maruyama, S. (2009) Antihypertensive effect of enzymatic hydrolysate of collagen and Gly-Pro in spontaneously hypertensive rats. Biosci. Biotechnol. Biochem. 73, 2317-2319.

10. Kaya, S. and Tekin, A. R. (2001) The effect of salep content on the rheological characteristics of a typical ice cream mix. J. Food Eng. 47, 59-62.

11. Kilara, A. and Chandan, R. C. (2008) Ice cream and frozen desserts. In: Dairy Processing \& Quality Assurance. Chandan, R.C. (ed) Wiley-Blackwell, Oxford, pp. 364-365.

12. Kim, J. H., Jeong, K. H., Shim, J. B., Jeong, Y. K., Jang, M. Y., Jo, Y. J., Min, S. G., and Chun, J. Y. (2014) Effect of super- or sub-critical water treatment on physicochemical properties of pig skin. P 13-033, 2014 Annual Meeting of Korean Society of food Sci. and Technol., Gwangju, Korea, pp. 164-165.

13. Kim, S. K., Kim, Y. T., Byun, H. G., Park, P. J., and Ito, H. (2001) Purification and characterization of antioxidative peptides from bovine skin. J. Biochem. Mol. Biol. 34, 214-219.

14. Kokini, J. L. (1987) The physical basis of liquid food texture and texture-taste interactions. J. Food Eng. 6, 51-81.

15. Kus, S., Altan, A., and Kaya, A. (2005) Rheological behavior and time-dependent characterization of ice cream mix with 
different salep content. J. Texture Stud. 36, 273-288.

16. Lee, M. Y., Choi, Y. C., Chun, J. Y., Min, S. G., and Hong, G. P. (2013) Effects of high pressure/high temperature processing on the recovery and characteristics of porcine placenta hydrolysayes. Korean J. Food Sci. An. 33, 474-480.

17. Marshall, R. T., Goff, H. D., and Hartel, R. W. (2003) Ice cream. 6th ed, Kluwer Academic/Plenum Publishers, NY, pp. $1-34$.

18. Morris, E. R. (1995) Polysaccharide rheology and in-mouth perception. In: Food polysaccharides and their applications. Stephen, M. A. (ed) Marcel Dekker Inc, NY, pp. 515-546.

19. Muhr, A. H., Blanshard, J. M. V., and Sheard, S. J. (1986) Effects of polysaccharide stabilizers on the nucleation of ice. $J$. Food Technol. 21, 587-603.

20. Nagarajan, M., Benjakul, S., Prodpran, T., Songtipya, P., and Kishimura, H. (2012) Characteristics and functional properties of gelatin from splendid squid (loligo formosana) skin as affected by extraction temperatures. Food Hydrocolloid. 29, 389-397.

21. Penninger, J. M. L., Kersten, R. J. A., and Baur, H. C. L. (2000) Hydrolysis of diphenylether in supercritical water: Effects of dissolved nacl. J. Supercrit. Fluid. 17, 215-226.

22. Ravber, M., Knez, Ž., and Škerget, M. (2015) Simultaneous extraction of oil- and water-soluble phase from sunflower seeds with subcritical water. Food Chem. 166, 316-323.

23. Rincon, F., Leon de Pinto, G., and Beltran, O. (2006) Behav- ior of a mixture of Acacia glomerosa, Enterolobium cyclocarpum and Hymenaea courbaryl gums in ice cream preparation. Food Sci. Technol. Int. 12, 13-17.

24. Soukoulis, C., Chandrinos, I., and Tzia, C. (2008) Study of the functionality of selected hydrocolloids and their blends with $\mathrm{K}$-carrageenan on storage quality of vanilla ice cream. Food Sci. Technol. 41, 1816-1827.

25. Soukoulis, C., Lebesi, D., and Tzia, C. (2009) Enrichment of ice cream with dietary fibre: effects on rheological properties, ice crystallisation and glass transition phenomena. Food Chem. 115, 665-671.

26. Stanley, N. I. and Taylor, L. J. (1993) Rheological basis of oral characteristics of fluid and semi-solid foods: A review. Acta. Psychol. 84, 79-92.

27. Wang, S. Y., and Damodaran, S. (2009) Ice-structuring peptides derived from bovine collagen. J. Agric. Food Chem. 57, 5501-5509.

28. Watchararuji, K., Goto, M., Sasaki, M., and Shotiprunk, A. (2008) Value-added subcritical water hydrolysate from rice bran and soybean meal. Bioresour. Technol. 99, 6207-6213.

29. Wildmoser, H., Scheiwiller, J., and Windhab, E. J. (2004) Impact of disperse microstructure on rheology and quality aspects of ice cream. LWT-Food Sci. Technol. 37, 881-891.

30. Zhu, G. Y., Zhu X., Fan, Q., and Wan, X. L. (2011) Raman spectra of amino acids and their aqueous solutions. Spectrochim. Acta, Part A, 78, 1187-1195. 